\title{
SISTEM INFORMASI GEOGRAFIS PERSEBARAN MASYARAKAT MISKIN (DAMASKIN) DI DESA MONGGAS BERBASIS WEB
}

\author{
Wire Bagye ${ }^{1}$, Lalu Zaenul Haqiqi ${ }^{2}$, Maulana Ashari ${ }^{3}$ \\ ${ }^{1}$ Program Studi Sistem Informasi STMIK Lombok \\ ${ }^{2}$ Program Teknik Informatika STMIK Lombok \\ 3 Program Studi Sistem Informasi STMIK Lombok \\ 1wirestmik@gmail.com, 2laluzaenul23@gmail.com,3aarydarkmaul@gmail.com
}

\begin{abstract}
Monggas Village is in the Kopang Subdistrict area with a population of 7125 people and 3272 poor people. The number of poor people in Monggas Village is relatively high with a number in each hamlet. The Monggas Village Government has data on the poor with regular data collection. The poor data is stored in Microsoft Office Excel files. In the file contains the biodata of the community and the full address but it cannot display data in the form of maps, routes or images. If you are going to make a visit, the search for residential locations is done conventionally, namely search of addresses starting from the hamlet, RT and endapatkn information from the community. This is also an obstacle for the related stakeholders to tracer the addresses of the poor for various assistance and re-registration needs.

Geographical information system is built. Distribution of web-based poor communities in Monggas. The method used in designing geographic information systems The distribution of the poor is the System Development Life Cycle (SDLC). There are four stages in this research, namely the system analysis stage, system design phase, trial phase, and system testing stage.

This Geographic information system can provide information to related agencies that need data on the distribution of disadvantaged people in the village of Monggas, Kopang Subdistrict, Central Lombok District. This Geographic Information System provides information in the form of population data in each hamlet. The system also displays the address of the coordinates of the house so that it can be explored faster.
\end{abstract}

Keywords: GIS, Distribution of the Poor, SDLC.

\begin{abstract}
Abstrak
Desa Monggas masuk wilayah Kecamatan Kopang dengan jumah penduduk 7125 jiwa dan 3272 jiwa masyarakat miskin. Jumlah masyarakat miskin di Desa Monggas relative tinggi dengan sebran pada setiap dusun. Pemerintah Desa Monggas memili data masyarakat miskin dengan pendataan secara berkala. Data masyarakat miskin tersebut disimpan dalam file microsoft office excel. Dalam file tersebut berisi biodata masyarakat dan alamat lengkap nmun tidak dapat menampilkan data berupa peta, rute maupun gambar. Jika akan melakukan kunjungan maka pencarian lokas tempat tinggal dilakukan secara konvensional yaitu penelusuran alamat mulai dari dusun, RT dan endapatkn informasi dari masyarakat. Hal ini enjad kendala bagi stekholder terkait unruk melakukan tracer alamat masyarakat miskin untuk berbagai keperluan pendampingan dan pendataan ulang.

Dibangun sistem informasi geografis Persebaran masyarakat miskin desa Monggas berbasis web. Metode yang digunakan dalam merancang sistem informasi geografis Persebaran masyarakat miskin ini adalah System Development Life Cycle (SDLC). Ada empat tahap dalam pnelitian ini yaitu tahap analisis sistem, tahap perancangan sistem, tahap uji coba, dan tahap pengujian sistem.

Sistem informasi Geografis ini dapat memberikan informasi kepada dinas terkait yang membutuhkan data persebaran masyarakat kurang mampu yang ada di desa Monggas Kecamatan kopang kabupaten lombok tengah Sistem Informasi Geografis ini memberikan informasi berupa data penduduk pada setiap dusun. System juga menampilkan alamat koordinat rumah sehingga dapat ditelussuri lebih cepat.
\end{abstract}

Kata kunci : SIG, Persebaran Masyarakat Miskin, SDLC. 


\section{Pendahuluan}

Di desa Monggas Belum mempunyai sistem informasi berbasis web yang memuat lokasi atau tempat tinggal masyarakat kurang mampu yang tersebar di Desa Monggas mengakibatkan berbagai pihak kesulitan untuk mendapatkan informasi serta menyalurkan bantuan terutama pada lokasi-lokasi terpencil, Data tentang keadaan penduduk dan jumlah penduduk Desa Monggas Kecamatan Kopang pada tahun 2017 berjumlah sekitar 7125 jiwa dengan 2309 kepala keluarga yang terdiri dari enam yaitu Dusun Bage dengan 1253 penduduk, Dusun Lopan 1221 penduduk, Dusun Sabi 1119 penduduk, Dusun Bajur 1464 penduduk, Dusun Monggas I 859 penduduk dan Monggas II 1209 penduduk dengan 3272 masyarakat miskin.

Informasi dan data tentang masyarakat miskin di desa Monggas ini sangat penting agar bantuan yang diberikan bisa tepat sasaran dan penurunan angka kemiskinan bisa tercapai. Oleh karena itu, perlu adanya peran sistem informasi untuk mengidentifikasi masyarakat yang kurang mampu serta data-data rumah tangga kurang mampu yang lengkap dan akurat sehingga bantuan yang disalurkan bisa tepat pada sasaran yang dituju. Salah satu sistem informasi identifikasi yang dapat digunakan adalah Sistem Informasi Geografis (SIG). SIG sangat efisien dalam hal menyimpan, memanipulasi, menganalisa, dan menampilkan kembali data geografis dengan bantuan data spasial dan data attribut. SIG diharapkan dapat menjadi solusi dan dijadikan sarana untuk mengidentifikasi serta melakukan pemetaan (mapping) terhadap wilayah yang memiliki masyarakat yang kurang mampu sehingga dapat dijadikan sarana penyaluran bantuan yang akan di berikan oleh pemerintah maupun pihak lainnya. Pembangunan sistem informasi geografis penyebaran masyarakat kurang mampu di Desa Monggas disajikan dengan menggunakan teknologi web. Tujuan penggunaan teknologi web pada SIG akan mempermudah berbagai pihak untuk mengakses informasi data masyarakat kurang mampu kapan pun dan dimana pun melalui internet, karena web dapat diakses dengan mudah melalui perangkat desktop dan mobile.

\section{Pustaka dan Teori}

\section{A. Tinjauan Pustaka}

Pelatihan Sistem Informasi Geografis (SIG) Kepada Perangkat Gampong Dalam Pembuatan Peta Potensi Gampong Di Gampong Keumuning Peut Kecamatan Darul Aman Kabupaten Aceh Timur Identifikasi potensi suatu gampong dapat digambarkan kedalam bentuk peta, apabila peta dilengkapi dengan informasi sumberdaya lahan dan sumberdaya manusia yang menjadi sumber pendapatan perekonomian gampong tersebut.Sumberdaya lahan dapat digambarkan berdasarkan sebaran luas dari penggunaan lahan seperti sebaran luas sawah, luas perkebunan kelapa sawit, luas perkebunan kelapa.Sedangkan sumberdaya manusia dapat dilihat berdasarkan usaha kecil menengah didalam gampong tersebut. Permasalahan yang dihadapi saat ini adalah gampong keumuneng peut belum memiliki peta Gampong, maka perlu dilakukan suatu pemahaman kepada perangkat dan masyarakat tentang cara melakukan pembuatan peta potensi di gampong keumuneng peut. memberikan pemahaman tentang pembuatan peta dan memberikan informasi tentang potensi Gampong yang ada saat ini sehingga perangkat Gampong dapat mengetahui tentang pembuatan peta potensi gampong.. Manfaat yang diharapkan masyarakat pada umumnya dan khususnya perangkat gampong dapat memahami sistem kerja dalam pembuatan peta gampong. Gampong Keumuneng Peut akan memiliki peta batas dusun dan desa, peta fasilitas gampong, dan peta yang menggambarkan potensi gampong dan perangkat gampong mampu mengelola peta secara mandiri dalam memberikan informasi baru di masa yang akan datang setelah terlaksananya pelatihan. Pelaksanaan pengabdian masyarakat ini dilaksanakan di Gampong Keumuneng Peut Kecamatan Darul Aman Kabupaten Aceh Timur[2].

Sistem Informasi Geografis Manajemen Data Kependudukan Kecamatan Sambutan Kota Samarinda Berbasis Website Penelitiannya untuk memanajemen pemutakhiran data kependudukan dan menganalisis pengaruh pertumbuhan penduduk di masing masing kelurahan di kecamatan Sambutan. Data yang digunakan 
dalam penelitiannya adalah data sekunder dari kecamatan sambutan Kota Samarinda dalam jangka waktu 1 tahun. Tujuan dari Sistem informasi geografis dengan memetakan data kependudukan berfungsi untuk memudahkan mendata, memanajemen dan melakukan perubahan atau updating data kependudukan setiap waktu berdasarkan perubahan data yang diperlukan. Pada penelitian ini menghasilkan sebuah sistem informasi geografis manajemen data kependudukan kecamatan sambutan kota samarinda berbasis website[3].

Sistem Informasi Geografis Pemetaan Tingkat Pertumbuhan Penduduk Berbasis Web Peningkatan jumlah penduduk di Kota Denpasar dikarenakan Kota Denpasar menjadi pusat pemerintahan Provinsi dan Kota. Faktor yang menyebabkan terjadinya pertumbuhan penduduk yaitu kelahiran (fertilitas), kematian (mortalitas), dan perpindahan penduduk (migrasi) Sistem informasi geografis pemetaan tingkat pertumbuhan penduduk berbasis Web dapat melakukan proses manajemen data pertumbuhan penduduk dalam bentuk digital yang dapat disimpan, diakses dan diubah sewaktu-waktu. Proses pencarian dan penambahan data telah melalui proses validasi sehingga mampu meminimalisir kesalahan saat melakukan penambahan maupun pencarian data penduduk. Sistem Informasi Geografis Pemetaan Tingkat Pertumbuhan Penduduk memberikan informasi berupa data pertumbuhan penduduk yang ditampilkan secara spasial pada peta dengan indikator warna yang beragam kepekatannya pada setiap wilayah. Maka hasil dari penelitian ini ialah Sistem Informasi Geografis Pemetaan Tingkat Pertumbuhan Penduduk Berbasis Web[5].

Aplikasi Sistem Informasi Geografis Untuk Pengelolaan Padi Di Pulau Jawa Berbasis Web yang tujukan untuk pengelolaan padi di pulau jawa untuk mengatasi tantangan dan ancaman Pertanian Padi khususnya di Pulau Jawa. Tujuan dari penelitian ini adalah Membangun suatu aplikasi berkonsep Web GIS Menyajikan informasi guna mendukung fungsi manajemen dan pengambilan keputusan[7].
Pertanian Padi di Pulau Jawa melalui akses pemetaan WebGIS terkait posisi, estimasi dan potensi luas lahan, potensi tanaman padi berdasarkan tingkat pertumbuhan (Growth Stage), dan pemantauan lahan dan tanaman padi. Menyajikan data statistik dalam bentuk popup pada peta, tabel dan diagram terkait informasi padi di pulau Jawa. Mempermudah dalam penyampaian informasi terkait Pertanian Padi di Pulau Jawa berupa data spasial dan data atribut kepada user yang mengakses web tersebut hasil dari penelitian ini ialah sistem informasi berbasis web gis dan menyelesaikan masalah yang ada.

Sistem Informasi Data Kemiskinan Kabupaten Banyuasin Sumatera Selatan Permasalahan yang sering terjadi dalam menjalankan program-program pengentasan kemiskinan adalah tidak sesuainya antara program yang disiptakan oleh Pemerintah Daerah dengan masalah yang dihadapi oleh masyarakat yang ada dilapangan, bahkan mungkin bisa dikatakan masyarakat tujuan yakni masyarakat miskin sama sekali tidak pernah tersentuh oleh program-program pemerintah, sehingga hasil yang diperoleh bisa dikatakan jauh dari harapan dikarenakan data penduduk miskin tidak tertata dengan baik, sehingga program pemerintah dalam mengentaskan kemiskinan belum tepat sasaran. Tujuan dari Sistem Data Kemiskin (SIMDASKIN) Membangun basis data rumah tangga miskin yang akurat untuk dijadikan acuan dalam penyusunan program penghapusan kemiskinan serta dapat Mengevaluasi hasil program penghapusan kemiskinan yang terukur dan dapat dirasakan langsung oleh masyarakat. Hasil dari penelitian tersebut mennghasil suatu Sistem Informasi Data Kemiskinan yang disingkat dengan (SIMDASKIN), sistem ini dapat memberikan informasi yang lengkap dan akurat sesuai dengan kriteria kemiskin serta ditampilkan dalam bentuk tabel dan grafik[8].

\section{B. Sistem Informasi Geografis}

Informasi geografis, dalam bentuk yang paling sederhana, adalah informasi yang berkaitan dengan lokasi tertentu (Martin, 1996:1). Dalam arti luas, Geographic information system merupakan alat bantu 
dalam memproses data spatial menjadi sebuah informasi (DeMers, 1997:7). GIS bukan sekedar penggunaan komputer untuk membuat peta, tapi lebih dari itu GIS seharusnya dapat membantu dalam analisis. Menurut Martin (1996:3)[1].

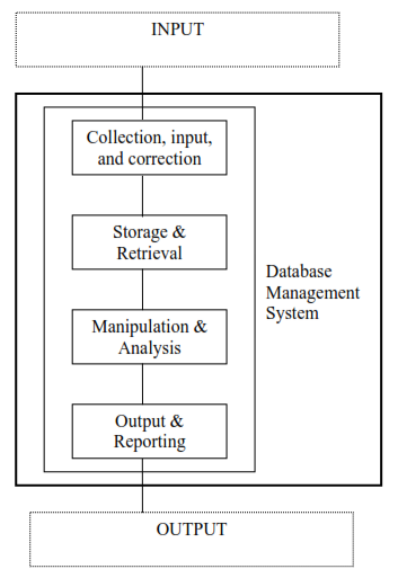

Gambar 2.1. Alur Proses GIS [1]

GIS memiliki 4 komponen utama, yaitu:

1. Collection, input and correction adalah operasi yang menekankan pada penerimaan/pengumpulan data dalam sistem, termasuk digitasi manual, scanning, keyboard entry, dan penarikan online dari sistem database lain. Pada tahap ini peta digital pertama kali dibangun.

2. Mekanisme Storage and retrieval termasuk kontrol fasilitas penyimpanan data dalam memory, disket atau tape, dan mekanisme penarikannya untu melayani kebutuhan ketiga komponen sistem berikutnya.

3. Manipulation and analysis menampilkan keseluruhan teknik yang tersedi dalam transformasi model digital menggunakan mathematical mean. Ini merupakan inti dari GIS, dan yang membedakannya dengan Compute Assisted Cartography. Sekumpulan algoritma data processing tersedia untuk tranformasi data spasial, dan hasil dari manipulasi data dapat ditambahkan pada database digital dan dihubungkan dengan visualisasi baru dari sebuah peta.

4. Output and reporting meliputi proses mengelurakan data dari sistem dala komputer atau bentuk lain yang dapat dibaca. Ini merupakan tahap diman pengguna database digital dapat secara selektif membuat peta analog baru.

Empat operasi mendasar dari GIS

1. Reclassification operation, merubah informasi atribut yang berhubungan dengan cakupan satu peta. Ini dapat dianggap sebagai sebuah 'pewarnaan sederhana atas objek analisis. Misalnya peta kepadatan penduduk dapat dikalsifikasikan menjadi 'daerah padat' atau 'kurang padat' tanpa merujuk ke data lain.

2. Overlay operation meliputi kombinasi dua atau lebih peta, dan hasilnya merupakan delienasi dari boundaries baru.

3. Distance and connectivity measurement meliputi pengukuran sederhana dari jarak antar titik dan operasi yang lebih kompleks, misalnya pembentukan zona.

4. Neighbourhood characterization meliputi pemberian nilai pada lokasi sesua karakteristik dari region di sekitarnya. Operasi yang dilakukan bisa berbentuk penjumlahan atau rata-rata dari variabel termasuk penghalusan dan perluasan boundaries.

\section{Google map API}

Google Maps API adalah library JavaScript. untuk menggunakan memprogram Google Maps API dibutuhkan pengetahuan tentang HTML dan JavaScript, serta koneksi Internet. Dengan menggunakan Google Maps API dapat menghemat waktu dan biaya Anda untuk membangun aplikasi peta digital yang handal, sehingga Anda dapat focus hanya pada data. Saat ini versi terakhir Google Map API adalah versi 3. Versi ini lebih cepat tampil dibandingkan versi sebelumnya khususnya untuk browser ponsel[6].

\section{Analisis SWOT}

Teori SWOT (Strengths- WeaknessesOpportunities- Threats) menurut Wheelen dan Hunger[6]. Merupakan sebuah langkah untuk dapat mengidentifikasi faktor internal dan eksternal yang berpengaruh terhadap pencapaian tujuan organisasi. Lingkungan 
eksternal berisi variabel peluang dan ancaman (oppoturnities and threats) yang berada di luar organisasi dan bukan merupakan hal yang dapat dikontrol oleh pimpinan organisasi dalam jangka waktu dekat. Lingkungan internal organisasi terdiri dari variabel kekuatan dan kelemahan (strenghts and weaknesses) yang berada dalam tubuh organisasi itu sendiri dan biasanya tidak dalam kontrol pimpinan organisasi dalam waktu dekat. Yang termasuk dalam variabel ini adalah struktur, budaya, dan sumber daya organisasi.

Analisa SWOT menggunakan Balanced Score Card yang bertujuan untuk mengetahui informasi strategis apa saja yang harus dikumpulkan sebelum menyusun SWOT Balance Scorecard [4]. Sebelum mulai menyususn SWOT Balance Score card kumpulkan semua informasi strategis yang dibutuhkan dalam penyusunana SWOT Balance Scorecard untuk Informasi yang berhubungan dengan perusahaan ialah:

1. Rencana Strategis dibandingkan dengan kondisi saat ini

2. Rencana finansial dibandingkan dengan kondisi saat ini

3. Rencana pemasaran dibandingkan dengan kondisi saat ini

4. Rencana pengoperasian dibandingkan dengan kondisi saat ini

5. Laporan tahunan

6. Program peningkatan kualitas

7. Anlisis pelanggan

8. Wawancara dengan manajemen eksekutif

9. Dokumen oerencanaan penunjanag lainnya

\section{Metodologi Penelitian}

\section{A. Analisa}

Analisis SWOT menurut Jogiyanto (2005:46) sangat diperlukan dalam menilai kekuatan maupun kelemahan dari sumber daya yang dimiliki oleh perusahaan serta menilai kesempatan eksternal maupun tantangan yang di hadapi. Analisis swot mempunyai tahapan-tahapan sebagai berikut (strength) Kekuatan, (weaknes) Kelemahan, (opportunity) Peluang, dan, (threats) Ancaman.

Dari beberapa solusi yang ditawarkan, peneliti memilih untuk membuat sebuah sistem informasi geografis persebaran masyarakat miskin damaskin di desa monggas berbasis web.

\begin{tabular}{|c|c|l|}
\hline No & Analisis & \multicolumn{1}{|c|}{ Sistem Berjalan } \\
\hline 1 & $\begin{array}{l}\text { Kekuatan } \\
\text { strength) }\end{array}$ & $\begin{array}{l}\text { Dapat menerima } \\
\text { informasi persebaran } \\
\text { masyakrakat miskin } \\
\text { secara lebih jelas dari } \\
\text { sekretaris dan staf desa } \\
\text { monggas. }\end{array}$ \\
\hline 2 & $\begin{array}{l}\text { Kelemahan } \\
\text { (weakness) }\end{array}$ & $\begin{array}{l}\text { Tidak dapat di akses } \\
\text { semua pihak dan Harus } \\
\text { mendatangi kantor } \\
\text { desa monggas untuk } \\
\text { mendapatkan data } \\
\text { masyarakat miskin }\end{array}$ \\
\hline 3 & $\begin{array}{l}\text { Peluang } \\
\text { (opportunity) }\end{array}$ & $\begin{array}{l}\text { Membangun sistem } \\
\text { informasi geografis } \\
\text { persebaran masyarakat } \\
\text { miskin di desa monggas } \\
\text { untuk mendapatkan } \\
\text { data yang valid. }\end{array}$ \\
\hline 4 & $\begin{array}{l}\text { Bantuan yang } \\
\text { disalurkan tidak tepat } \\
\text { sasaran dan angka } \\
\text { kemiskinan tidak akan } \\
\text { menurun }\end{array}$ \\
\hline
\end{tabular}

\section{B. Diagram alir sistem}

Tabel 3.1 Flowmap Sistem Usulan

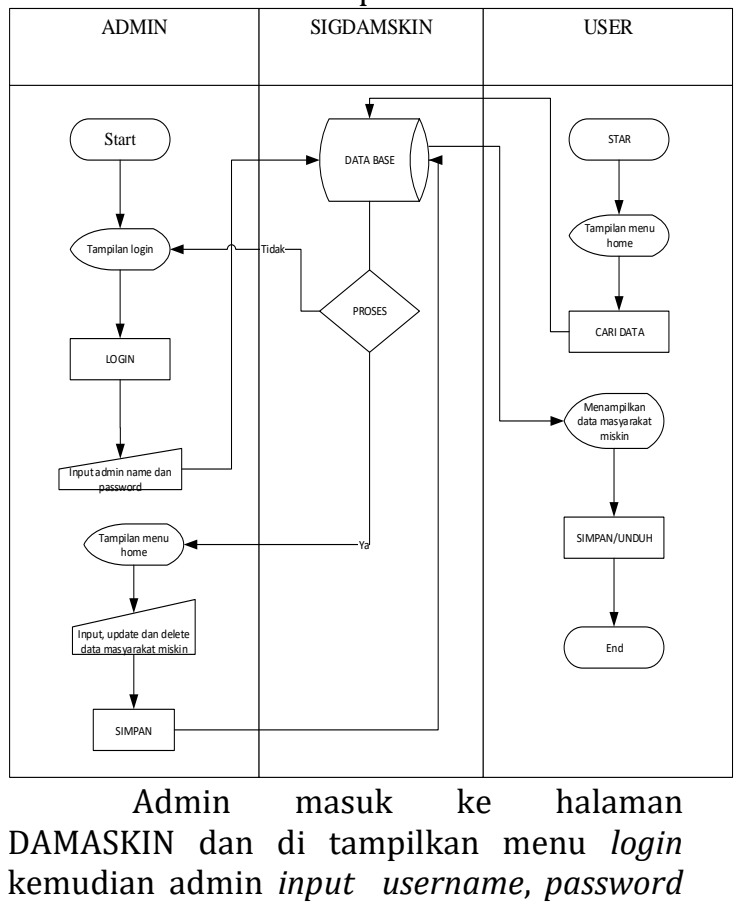


dan diproses kedalam database jika username dan password salah akan di kembalikan ke menu login jika benar akan di lanjutkan ke halaman menu home admin kemudian input data masyarakat miskin dan menyimpanya ke dalam database.

Pengunjung membuka halaman DAMASKIN untuk user dan di tampilkan menu home user kemudian mencari data yang sudah tersimpan di dalam database user dapat mengunduh dan menyimpan data.

\section{Perancangan Proses}

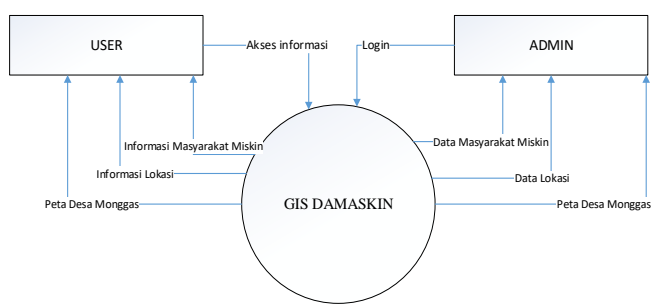

Gambar 3.1 Diagram Konteks Gis Damaskin

Menjelaskan secara umum alur sistem yang di usulkan, dari berbagai data seperti data masyarakat miskin, data lokasi dan data wilayah. Data tersebut kemudian di akses oleh user atau pengguna sebagai suatu informasi, seperti informasi masyarakat miskin di wilayah desa monggas dan Admin mengakses Sig damaskin (sistem informasi geografis data masyarakat miskin) Admin login menggunakan admin name dan password admin dan masuk ke Sig damskin. Tugas admin adalah menginput, mengupdate dan menghapus data masyarakat miskin.

\section{Hasil dan Pembahasan}

A. Interface

1. Halaman Login

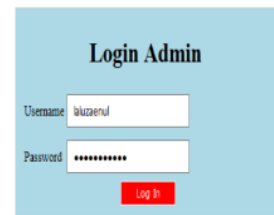

Gambar 4.1. Halaman Login Admin

Halaman login admin yang di gunakan untuk menyimpan data seperti username dan password. Halaman ini berfungsi sebagai pembatas antara user dan admin.

\section{Halaman Home Admin}

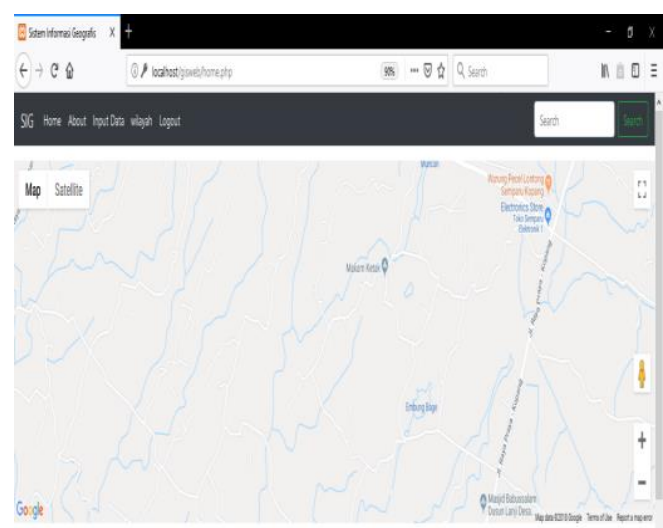

Gambar 4.2. Halaman Home

Tampilan halaman home menampilkan peta desa monggas.

\section{Halaman about}

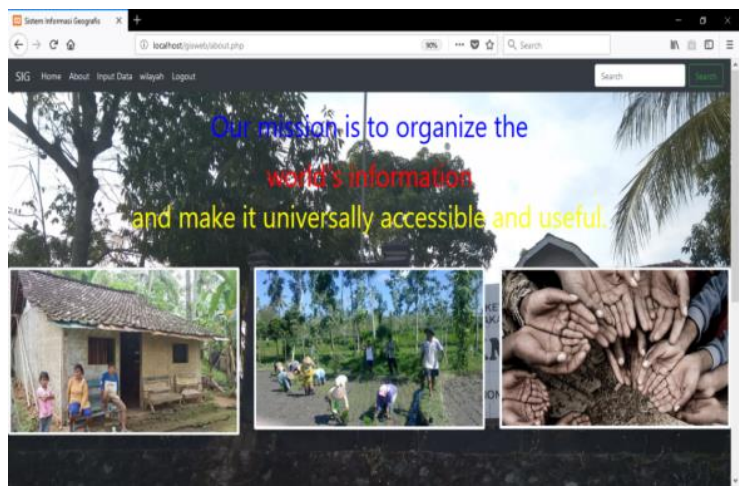

Gambar 4.3. Halaman about

Halaman about yaitu berisi informasi tentang aplikasi Sistem informasi geografis persebaran masyarakat miskin desa monggas Halaman ini berisikan tentang tujuan dari aplikasi

\section{Halaman Input Data}

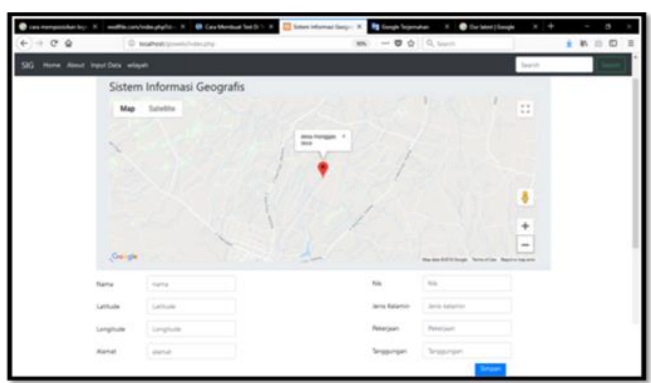

Gambar 4.4. Halaman Input Data 
Pada halaman ini yaitu untuk menginput data masyarakat miskin data yang tersimpan dapat di tampilkan berupa tabel yang di tampilkan di menu halaman data dan dapat di tampilkan berupa peta yang di tampilkan di menu wilayah.

\section{Halaman Data}

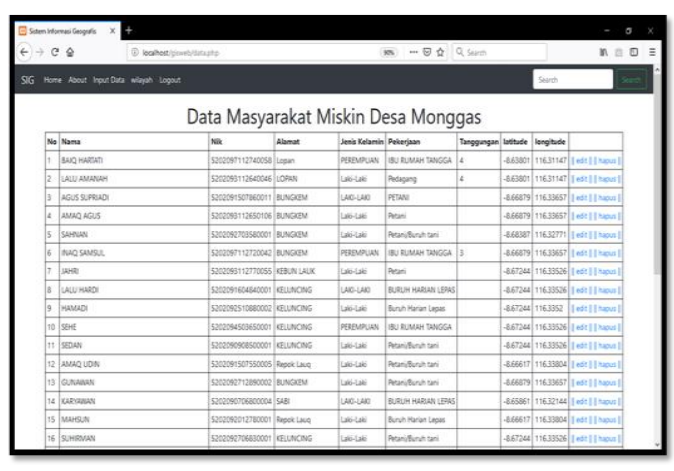

Gambar 4.5. Halaman Data

Halaman data yaitu menampilkan data yang sudah diinputkan berupa tabel. Admin dapat merubah dan menghapus data yang telah tersimpan di dalam database.

\section{Halaman Form Wilayah}

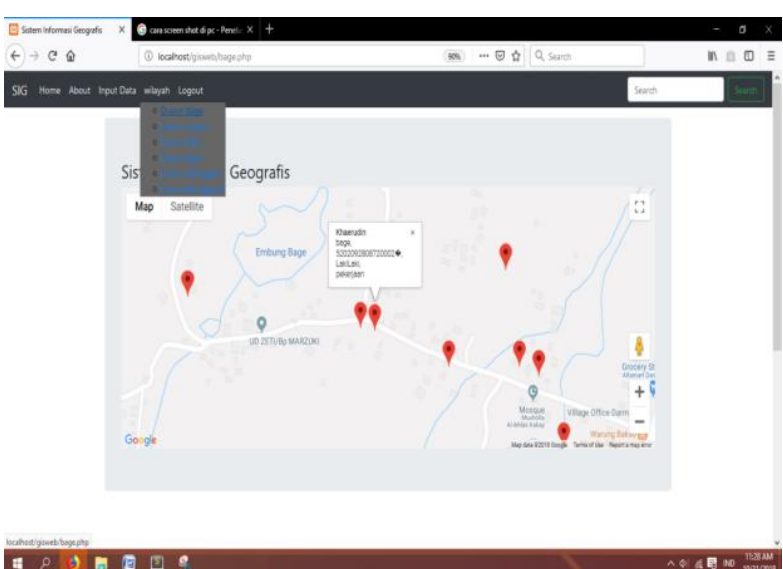

Gambar 5.6. Form Wilayah

Halaman ini menampilkan data persebaran lokasi alamat masyarakat miskin berdasarkan wilayah dusun.

\section{Kesimpulan dan saran}

\section{A. Kesimpulan}

Kesimpulan dari hasil perancangan dan implementasi sistem informasi geografis persebaran masyarakat miskin ini dapat disimpulkan sebagai berikut :

1. Dengan adanya sistem informasi geografis Persebaran Masyarakat miskin di Desa Monggas ini mempermudah dalam pencarian data.

2. Dengan adanya sistem informasi geograpis persebaran masyarakat miskin di desa monggas ini petugas menampilkan data berupa peta beserta mengtahui lokasi alamat masyarkat miskin.

3. Dapat Merancang dan membangun sebuah sistem informasi geografis Persebaran Masyarakat Kurang Mampu Di Desa Monggas sehingga dapat mempersingkat waktu dalam pencarian lokasi alamat masyarakat kurang mampu.

\section{B. Saran}

Dari rancangan sistem yang telah direalisasikan pada laporan Tugas Akhir ini diharapkan dapat menjadi dasar penelitian lebih lanjut, Saran yang diberikan untuk pengembangan agar dapat lebih baik adalah sebagai berikut:

1. Pada pengembangan sistem selanjutnya sistem mampu mengurutkan data berdasarkan wilayah.

2. Pada pengembangan sistem selanjutnya sistem mampu menampilkan rute munuju lokasi yang ditentukan.

\section{Daftar Pustaka:}

[1] Cholid, Sofyan, and Menurut Martin. "Sistem Informasi Geografis: Suatu Pengantar." Bogor: Staff Akademik Departemen Ilmu Kesejahteraan Sosial FISIP UI (2009).

[2] Gampong, Peta Potensi. "Pelatihan Sistem Informasi Geografis (Sig) Kepada Perangkat Gampong Dalam Pembuatan Peta Potensi Gampong Di Gampong Keumuning Peut Kecamatan Darul Aman Kabupaten Aceh Timur." Seminar Nasional Teknik Industri [SNTI2017] Lhokseumawe. 2017

[3] Noor, Alfian, Haeruddin Haeruddin, and Rudiman Rudiman. "Sistem Informasi Geografis Manajemen Data Kependudukan Kecamatan Sambutan Kota Samarinda Berbasis 
Website." Prosiding SAKTI (Seminar Ilmu Komputer dan Teknologi Informasi). Vol. 2. No. 1. 2017.

[4] Lombok, K. I. S. (2015). Perencanaan Strategi Sistem Informasi Pendidikan Pada Sekolah Tinggi Manajemen Informatika dan Komputer (STMIK) Lombok. Bianglala Informatika, 3(2).

[5] Lukman, M., Bagye, W., Fahmi, H., \& Imtihan, K. (2019). PEMANFAATAN TEKNOLOGI GOOGLE MAPS API UNTUK APLIKASI PENDETAKSIAN LOKASI RAWAN KRIMINALITAS BERBASIS ANDROID Studi kasus: Desa Ganti dan Desa Mujur, Kecamatan Praya Timur, Kabupaten Lombok Tengah. Jurnal Informatika dan Rekayasa Elektronik, 2(1), 52-59.

[6] Rangkuti, Freddy. Analisis SWOT teknik membedah kasus bisnis. Gramedia Pustaka Utama, 1998.

[7] Imtihan, K., Hadawiyah, R., \& Lombok, H. A. S. (2018). Sistem Informasi Penggajian Guru Honorer Menggunakan Konsep Agile Software Development dengan Metodologi Extreme Programming (XP) pada
SMK Bangun Bangsa. IJNS-Indonesian Journal on Networking and Security, $7(2)$.

[8] Setiadi, I. Made Dharmawan, I. Nyoman Piarsa, and $\mathrm{Ni}$ Made Ika Marini Mandenni. "Sistem Informasi Geografis Pemetaan Tingkat Pertumbuhan Penduduk Berbasis Web." Jurnal Ilmiah Merpati (Menara Penelitian Akademika Teknologi Informasi) (2015).

[9] Shodiq, Amri. "Tutorial Dasar Pemrograman Google Maps API." Map Direction (2009).

[10] Soelistio, Adi Tri, Tody Ariefianto Wibowo, and Agus Ganda Permana. "Aplikasi Sistem Informasi Geografis (Sig) Untuk Pengelolaan Padi Di Pulau Jawa Berbasis Web." eProceedings of Applied Science 1.1 (2015).

[11] Syakti, Firamon. "Sistem Informasi Data Kemiskinan Kabupaten Banyuasin Sumatera Selatan." Seminar Nasional Informatika (SEMNASIF). Vol. 1. No. 1. 2015. 